\title{
UPAYA MENINGKATKAN HASIL AKURASI SHOOTING OLAHRAGA SEPAKBOLA MELALUI MEDIA LINGKARAN KARET BAN PADA SISWA KELAS XI IPS 2 SMA NEGERI 03 BENGKULU TENGAH
}

\author{
Komplit raharjo \\ Universitas Bengkulu \\ KomplitRaharjo22@gmail.com \\ Syafrial \\ Universitas Bengkulu \\ Sugiyanto \\ Universitas Bengkulu
}

\begin{abstract}
Abstrak
Penelitian ini bertujuan untuk meningkatkan hasil akurasi shooting olahraga sepakbola melalui media lingkaran karet ban pada siswa kelas XI IPS 2 SMA Negeri 03 Bengkulu Tengah. Penelitian ini adalah penelitian tindakan kelas (classroom action research). Subjek penelitian siswa kelas XI IPS 2 SMA Negeri 03 Bengkulu Tengah yang berjumlah 28 siswa, yang terdiri dari 16 siswa laki-laki dan 12 siswi perempuan. Berdasarkan pengamatan dan informasi yang peneliti dapatkan, Olahraga sepak bola belum sepenuhnya dikuasai siswa terutama shooting bola ke gawang hal ini dapat dilihat dari penilaian kemampuan melakukan tendangan bola ke gawang. Hasil dari penelitian prasiklus dari 28 anak presentase hasil akurasi shooting ke gawang siswa adalah 30,5\%. Pada siklus I terdapat kenaikan yaitu $(60,7 \%)$. Sedangkan pada siklus II sebesar $78,5 \%$ tergolong baik. Ini menunjukan bahwa tindakan yang dilakukan disiklus kedua baik guru maupun siswa dapat dikatakan telah tuntas belajar. Berdasarkan hasil diatas maka disimpulkan bahwa dengan mengunakan media lingkaran karet ban dapat meningkatkan hasil akurasi shooting olahraga sepakbola.Sehubungan hasil penelitian tersebut, peneliti menyarankan kepada guru dan pembina dianjurkan lebih berperan selama pelaksanaan kegiatan belajar mengajar atau kegiatan ekstrakurikuler sehingga siswa lebih merespon dan antusias terhadap pembelajaran yang diberikan.
\end{abstract}

Kata kunci:Media lingkaran karet ban, Akurasi Shooting Sepak bola.

\begin{abstract}
This study aims to improve the accuracy of football sport shooting through rubber tire rubber circle in grade XI IPS 2 SMA Negeri 03 Bengkulu Tengah. This research is a classroom action research. The subjects of the research students of class XI IPS 2 SMA Negeri 03 Bengkulu Tengah, which amounted to 28 students, consisting of 16 male students and 12 female students. Based on observations and information that researchers get, Sports football has not fully mastered the students, especially shooting the ball into the goal this can be seen from the assessment of the ability to kick the ball into the goal. The result of the prasiklus research of 28 children the percentage of shooting accuracy results to the students' goal is $30.5 \%$. In the first cycle there is an increase (60.7\%). While in cycle II equal to $78,5 \%$ pertained good. This shows that the actions taken in the second cycle of both teachers and students can be said to have been thoroughly studied. Based on the above results, it is concluded that by using the rubber circle tire media can improve the accuracy of shooting sport football. In relation to the
\end{abstract}


results of these studies, researchers suggest to teachers and coaches are encouraged to play a role during the implementation of teaching and learning activities or extracurricular activities so that students are more responsive and enthusiastic about the learning given.

\section{Keywords: Media tire rubber circle, Accuracy Shooting Football.}

\section{PENDAHULUAN}

Pendidikan adalah sebagai usaha sadar dan terencana untuk mewujudkan suasana belajar dan proses pembelajaran untuk peserta didik secara aktif mengembangkan potensi dirinya untuk memiliki kekuatan spiritual keagamaan, pengendalian diri, kepribadian, kecerdasan, akhlak mulia, serta keterampilan yang diperlukan dirinya dan masyarakat. Pendidikan dapat diartikan sebagai usaha sadar dan sistematis untuk mencapai taraf hidup atau untuk kemajuan lebih baik. Secara sederhana, Pengertian pendidikan adalah proses pembelajaran bagi peserta didik untuk dapat mengerti, paham, dan membuat manusia lebih kritis dalam berpikir.

Dalam dictionary of education dinyatakan bahwa : :(a)Proses seseorang mengembangkan kemampuan, sikap, dan tingkah laku lainnya di dalam masyarakat tempat mereka hidup. (b)Proses sosial yang terjadi pada orang yang dihadapkan pada pengaruh lingkungan yang terpilih dan terkontrol (khususnya yang datang dari sekolah), sehingga mereka dapat memperoleh perkembangan kemampuan sosial dan kemampuan individu yang optimum." Menurut G Thompson dalam (Taufiq, 2012:3), menyatakan bahawa pendidikan adalah pengetahuan lingkungan atas individu untuk menghasilkan perubahanperubahan yang tetap di dalam kebiasaankebiasaan, pemikaran, sikap-siskap, dan tingkah laku. Artinya pendidikan disini bukan hanya sebagai pemberian informasi pengetahuan dan pembentukan keterampilan lebih luas dari pada itu, meliputi usaha untuk mewujudkan keinginan, kebutuhan dan kemampuan individu sehingga tercapai pola hidup pribadi dan sosial yang memuaskan.

Berdasarkan pengertian di atas hal ini membuktikan betapa pentingnya pendidikan. Perlu kita ketahui terkait bahwa pendidikan jasmani merupakan bagian integral dari pendidikan. Pendidikan jasmani tidak dapat dipisahkan dengan pendidikan secara umum. Karena pendidikan jasmani dan pendidikan adalah suatu kesatuan. Jadi ketika tubuh tanpa jantung maka tubuh akan cacat, demikian juga pendidikan tanpa pendidikan jasmani maka pendidikan tidak sempurna atau tidak dapat mencapai tujuan dari pendidikan tersebut. Pendidikan jasmani merupakan suatu bidang kajian ilmu tentang pendidikan dan jasmani. Dalam hal ini terdapat dua istilah, yaitu pendidikan dan jasmani. Pendidikan merupakan suatu proses memberikan pengetahuan baru, secara menyeluruh, serta pembimbingan manusia untuk dapat berkembang dan tumbuh secara optimal sehingga segala aspek yang ada dalam manusia mampu bersinergi dengan pengetahuan baru yang didapatkannya (Bayu Insanistyo dan Dian Pujianto, 2014 : 13).

Melalui proses pembelajaran Pendidikan Jasmani di sekolah ingin mewujudkan sumbangannya terhadap perkembangan anak yang tidak berat sebelah. Sumbangan yang diberikan dari Pendidikan Jasmani adalah memberikan perkembangan secara menyeluruh, karena yang dikembangkan bukan hanya aspek keterampilan gerak dan kebugaran jasmani (ranah jasmani dan psikomotorik), tetapi pengembangan ranah kognitif dan afektif juga dikembangkan. Dengan Pendidikan Jasmani, Olahraga, dan Kesehatan, akan diperoleh berbagai ungkapan yang erat kaitannya dengan kesan pribadi yang menyenangkan serta berbagai ungkapan yang 
kreatif, inovatif, terampil, memiliki kebugaran jasmani, kebiasaan hidup sehat dan memiliki pengetahuan serta pemahaman terhadap gerak manusia (Khairul dan Milka, 2010 : 6).

Pendidikan jasmani merupakan suatu hal yang paling mengasyikkan bagi setiap individu siswa. Permainan banyak manfaatnya bagi tubuh, maupun kesehatan kita salah satu permainan itu ada yang digemari adalah permainan sepak bola. Dimana permaianan ini sangatlah mudah dan menyebar diseluruh daerah. Apabila ada kemauan dapat dilakukan kapan saja. Permainan sepak bola akan mudah apabila siswa mampu menguasai teknik-teknik dalam permainan sepak bola, terutama dalam teknik dasar shooting.

Permainan sepak bola merupakan materi pelajaran yang dimasukan kedalam kurikulum nasional, dalam artian permainan olahraga sepak bola wajib diberikan, diajarkan pada siswa. Untuk dapat bermain sepak bola siswa harus menguasai teknik-teknik dasar permainan sepak bola dengan baik.

Pada observasi yang penulis lakukan pada tanggal 3 februari 2017 di SMA Negeri 03 Bengkulu Tengah pada pelajaran olahraga sepak bola, sarana penunjang seperti lapangan olahraga dan alat-alat kurang memadai. Kenyataan di lapangan ditemui bahwa siswa banyak yang kurang menguasai teknik dasar shooting sehingga akurasi shooting yang dimiliki tidak ada walaupun dalam permainannya siswa sudah menguasai sebagian tekniknya.

Siswa memiliki kecendrungan untuk belajar hal-hal yang baru dan penuh tantangan. Dengan kegemaran anak adalah mencoba hal-hal yang aneh dan baru. Oleh karena itulah, belajar bagi mereka adalah mencoba memecahkan setiap persoalan yang menantang. Dengan demikian, guru berperan dalam memilih bahan-bahan belajar yang dianggap penting untuk dipelajari siswa di jam pelajaran maupun di luar pelajaran.

Atas dasar realita yang terjadi di lapangan tersebut, maka penulis termotivasi untuk meneliti sehingga didapat gambaran yang berarti tentang "Upaya Meningkatkan Hasil Akurasi Shooting Olahraga Sepak Bola Melalui Media Lingkaran Karet Ban Pada Siswa Kelas XI IPS 2 SMA Negeri 03 Bengkulu Tengah".

\section{METODE}

Dalam penelitian ini metode yang digunakan adalah penelitian tindakan kelas (PTK). Penelitian tindakan kelas merupakan penelitian yang dilakukan untuk mengatasi permasalahan-permasalahan didalam kelas, penelitian tindakan kelas dapat dijadikan sarana bagi guru dalam meningkatkan kualitas pembelajaran secara efektif. PTK sering disebut dengan action research, dimana penelitian ini akan dilakukan melalui beberapa siklus dengan harapan akan terjadi adanya peningkatan terhadap hasil pembelajaran yang akan dicapai (Arikunto, 2006 : 7). Subjek penelitian ini adalah siswa-siswi kelas XI IPS 2 SMA Negeri 03 Bengkulu Tengah yang berjumlah 28 siswa yang masing-masing terdiri dari 16 siswa laki-laki dan 12 siswi perempuan.

Sesuai dengan maksud dan tujuan penelitian ini, Penelitian tindakan kelas dilakukan melalui proses yang dinamis dan komplementari yang terdiri dari empat momentum esensial yaitu perencanaan, pelaksanaan, observasi dan refleksi (Kunandar,2013:70). Dalam pengumpulan data, penulis menggunakan teknik observasi. Observasi adalah sebuah teknik pengumpulan data yang mempunyai ciri spesifik bila dibandingkan dengan teknik yang lain, yaitu wawancara dan kuisioner. Siswa setelah dilakukan tindakan maka dibutuhkan data hasil tes (pretest) yang diberikan sebelum siklus tindakan dimulai, data pretest akan diambil melalui tahapan prasiklus. Pada prinsipnya, meneliti adalah melakukan pengukuran, maka harus ada alat ukur yang baik. Alat ukur dalam penelitian biasanya dinamakan instrumen penelitian. Alat yang digunakan untuk mengukur pelaksanaan penelitian tindakan kelas di setiap siklusnya bentuk indikator dan penilaian hasil akurasi shooting tendangan ke gawang. Penilaian yang dilakukan adalah 
memberikan materi cara menendang bola ke gawang yang diberi lingkaran karet ban sebagai sasaran dan mudah untuk diingat serta untuk menghubungkan konsentrasi terhadap akurasi shooting yang baik.

\section{HASIL DAN PEMBAHASAN}

Hasil

Sebelum pelaksanaan pada siklus 1 , peneliti mengambil data tes awal akurasi shooting melalui media karet ban tanpa terlebih dahulu diberikan pembelajaran tentang keterampilan shooting sepakbola. Dari hasil tes awal akan tampak kemampuan dari siswa tersebut apakah sudah baik atau belum. Kalau sudah baik akan dipertahankan dan ditingkatkan lagi, dan seandainya masih kurang akan diberikan pembelajaran akurasi shooting pada pelaksanaan pembelajaran.

Melalui deskripsi data awal yang diperoleh, akan menunjukkan aspek-aspek mana yang masih kurang atau belum diketahui siswa dalam hal teknik shooting. Hasil dari pelaksanaan tes awal sebelum diberikan perlakuan dapat kita hitung sebagai berikut ; siswa dengan nilai tuntas: 10 siswa. Siswa dengan nilai tidak tuntas: 18 siswa.

\section{Siklus I}

Hasil dari tes pada siklus 1 yang telah dilaksanakan, menunjukkan bahwa ada peningkatan dari tes awal. Namun masih ada siswa yang belum menguasai teknik shooting sepakbola. Setelah diberi perlakuan kemampuan siswa menjadi lebih baik dari pada sebelum diberikan perlakuan pada tes pra siklus. Dari data tes siklus 1 di atas, sudah meningkat secara signifikan, secara keseluruhan meningkat menjadi $\mathbf{6 0 , 7} \%$ siswa kelas sudah mendapatkan nilai yang baik dalam melakukan akurasi shooting permainan sepakbola. Meskipun nilai siswa sudah meningkat secara klasikal namun nilai tersebut belum mencapai KKM mata pelajaran Penjaskes di sekolah, yaitu sebesar 75. Untuk itu penelitian ini akan dilanjutkan pada siklus 2, dengan mengidentifikasi kekurangan-kekurangan pada pelaksanaan pembelajaran siklus 1 . Sebelum pelaksanaan siklus 2 di minggu berikutnya, peneliti akan mendiskusikan hasil pada siklus 1 bersama teman sejawat dan guru pamong Penjaskes di sekolah tersebut.

\section{Siklus II}

Hasil pada siklus 2 ini akan dibandingkan dengan hasil dari siklus 1 . Pada siklus 2 telah diberi perlakuan kepada siswa bagaimana melakukan akurasi shooting dengan baik dan pemberian motivasi kepada siswa serta diberi kesempatan berlatih selama dua kali pertemuan pembelajaran, apakah kemampuan siswa akan bertambah baik setelah diberi pembelajaran. Dari data tes siklus 2 di atas, sudah meningkat dari tes pada siklus 1 , secara yang baik dalam melakukan akurasi shooting permainan sepakbola. Dari hasil yang didapat pada tes siklus 2 ini secara klasikal nilai tersebut telah mencapai KKM mata pelajaran Penjaskes di sekolah, yaitu sebesar 75. Dari hasil ini, penelitian tindakan kelas sudah mencapai tujuan dan harapan dari peneliti. Maka penelitian ini cukup sampai dengan siklus 2 saja.

\section{Pembahasan}

Berdasarkan prosedur penelitian tindakan kelas yang sudah dirancang dan dilaksanakan dengan sistematis, peneliti dapat mengumpulkan data penelitian yang mungkin dapat berupa informasi penting dari hasil penelitian. Penerapan pembelajaran akurasi shooting melalui media lingkaran karet ban dalam permainan sepakbola memberikan dampak positif kepada siswa. Dari prosesnya observasi awal hingga pelaksanaan pada siklus 2 terjadi peningkatan pada tiap pertemuannya. Pada tes awal sebelum diberikan perlakuan atau belum diberikan materi serta praktek melakukan akurasi shooting, hasil dari tes tersebut masih dalam kategori rendah secara klasikal. Secara keseluruhan siswa yang mendaptkan nilai dengan kategori baik hanya 
sebanyak 10 siswa atau dalam persentasenya sebesar $\mathbf{3 0 , 5} \%$.

Kemudian pada pertemuan 2 siklus 1 setelah diberikan materi teknik akurasi shooting sepakbola, kemampuan siswa menjadi meningkat, dengan siswa yang mendapatkan nilai dengan kategori baik sebanyak 17 siswa dengan persentase secara keseluruhan sebesar $\mathbf{6 0 , 7} \%$. Dari hasil tes pada siklus 1 walaupun mengalami peningkatan namun secara klasikal belum mencapai KKM mata pelajaran penjaskes sebsar 75. Untuk itu penelitian dilanjutkan pada siklus 2 dengan perbaikan-perbaikan di pertemuan berikutnya.

Setelah diberikan materi-materi tambahan tentang akurasi shooting melalui media lingkaran karet ban tersebut, hasil akurasi shooting meningkat dengan hasil tes pada siklus 2 sebanyak 22 siswa mendapatkan nilai dengan kriteria baik, dan secara persentase keseluruhan siswa pada kelas XI IPS 2 ini sudah mencapai KKM yaitu sebesar $\mathbf{7 8 , 5}$ \%. Dari hasil nilai tes pada siklus 2 yang sudah mencapai tujuan dari pembelajaran, maka penelitian tindakan kelas diakhiri pada siklus 2 saja tidak dilanjutkan untuk siklus berikutnya.

\section{PENUTUP}

\section{Simpulan}

Berdasarkan hasil analisis data dan pembahasan pada bab IV, simpulan yang didapat adalah kegiatan pembelajaran melalui media lingkaran karet ban dapat meningkatkan hasil akurasi shooting olahraga sepak bola pada siswa kelas XI IPS 2 SMA Negeri 03 Bengkulu Tengah. Persentase hasil belajar akurasi shooting ke gawang siswa di SMA Negeri 03 Bengkulu Tengah sebelum diberi metode melalui media lingkaran karet ban sebesar 30,5 \% tergolong rendah. Persentase hasil belajar akurasi shooting ke gawang siswa di SMA Negeri 03 Bengkulu
Tengah setelah diberikan metode melalui media lingkaran karet ban pada siklus I sebesar 60,7\% tergolong sedang. Persentase hasil belajar akurasi shooting ke gawang siswa di SMA Negeri 03 bengkulu Tengah setelah diberikan metode melalui media lingkaran karet ban pada siklus II sebesar 78,5\% tergolong baik.

\section{Saran}

Sehubungan dengan hasil dari penelitian mengenai upaya meningkatkan hasil akurasi shooting olahraga sepak bola melalui media lingkaran karet ban pada siswa kelas XI IPS 2 SMA Negeri 03 Bengkulu Tengah, maka penulis mengajukan saran-saran sebagai berikut :

1. Bagi pihak sekolah hendaknya menambah media selain media lingkaran karet ban dalam pembelajaran sepak bola sehingga setiap proses pembelajaran akan lebih efektif dan tujuan pembelajaran akan lebih mudah tercapai.

2. Bagi peneliti yang akan datang hendaknya mengadakan penelitian dengan populasi yang lebih luas dan sampel yang berbeda, sehingga faktor yang mempengaruhi persepsi terhadap hasil akurasi shooting melalui media lingkaran karet ban dalam pembelajaran sepakbola dapat teridentifikasi lebih luas.

\section{DAFTAR PUSTAKA}

Arikunto. (2006). Penelitian Tindakan Kelas. Jakarta: PT Bumi Aksara.

Bayu Insanistyo, Dian Puijianto. (2014). Manajemen Pendidikan Jasmani Olahraga. Fkip Universitas Bengkulu.

Hadziq, Khairul., Milka Nurfitri. (2010), Gelanggang Pendidikan Jasmani Olahraga dan Kesehatan. Jakarta: CV. Sinergi Pustaka Indonesia.

Kunandar,(2013). Penelitian Tindakan Kelas. Jakarta: PT RajaGrafindo Persada. 